MaPan : Jurnal Matematika dan Pembelajaran

p-ISSN: 2354-6883 ; e-ISSN: 2581-172X

Volume 7, No 2, December 2019 (229-248)

DOI: https://doi.org/10.24252/mapan.2019v7n2a5

\title{
MODEL PEMBELAJARAN KOOPERATIF DENGAN PENDEKATAN RECIPROCAL TEACHING DAN CONTEXTUAL TEACHING AND LEARNING TERHADAP KEMAMPUAN KOMUNIKASI MATEMATIKA SISWA
}

\author{
Bedilius Gunur1), Yohana Verawati Dangus'), Silfanus Jelatu ${ }^{3)}$ \\ 1,2,3Universitas Katolik Indonesia Santu Paulus Ruteng \\ 1,2,3Jl. Ahmad Yani, Ruteng-Flores, NTT \\ E-mail: Gbedilius@gmail.com ${ }^{1)}$, yohanaverawati13@yahoo.com²), \\ silfanusjelatu@yahoo.co.id ${ }^{3}$ )
}

Submitted: 13-09-2019, Revised: 29-10-2019, Accepted: 28-11-2019

\begin{abstract}
Abstrak:
Penelitian ini bertujuan untuk mengetahui keefektifan model pembelajaran kooperatif dengan pendekatan reciprocal teaching dan model pembelajaran kooperatif dengan pendekatan contextual teaching and learning serta membandingkan keefektifan dari kedua model pembelajaran terhadap kemampuan komunikasi matematika siswa kelas X SMK Santo Aloisius Ruteng. Penelitian ini merupakan penelitian eksperimen semu dengan desain penelitian pretest-posttest only control group design. Pengambilan sampel menggunakan teknik random sampling, dengan terlebih dahulu dilakukan uji kesetaraan kelas. Data dikumpulkan dengan menggunakan teknik tes yang berbentuk uraian. Data dianalisis dengan menggunakan uji t. Berdasarkan hasil analisis data diperoleh: (1) model pembelajaran kooperatif dengan pendekatan reciprocal teaching efektif terhadap kemampuan komunikasi matematika siswa; (2) model pembelajaran kooperatif dengan pendekatan contextual teaching and learning efektif terhadap kemampuan komunikasi matematika siswa; dan (3) model pembelajaran kooperatif dengan pendekatan reciprocal teaching lebih efektif dibandingkan model pembelajaran kooperatif dengan pendekatan contextual teaching and learning terhadap kemampuan komunikasi matematika siswa. Hasil penelitian ini diharapkan menjadi masukan bagi guru untuk terus melakukan inovasi pembelajaran dalam menunjang pencapaian hasil belajar siswa. Beberapa metode yang dapat digunakan adalah reciprocal teaching dan contextual teaching and learning.
\end{abstract}

Kata Kunci: Kooperatif, Reciprocal Teaching, Contextual Teaching and Learning, Komunikasi Matematika

COOPERATIVE LEARNING WITH RECIPROCAL TEACHING AND CONTEXTUAL TEACHING AND LEARNING (CTL) APPROACH FOR STUDENTS' MATHEMATICAL COMMUNICATION SKILLS

\begin{abstract}
:
This study aimed to know the effectiveness of cooperative learning with reciprocal teaching approach and the effectiveness of cooperative learning with contextual teaching and learning. It also compared the effectiveness between the two learning approaches toward the
\end{abstract}


mathematical communication skills of the tenth grade students in SMK Santo Aloisius Ruteng. This research used quasi-experimental design which used pretest-posttest. The population of this research was all the tenth grade students consisting of five classes. The sampling technique used was random sampling with equality test in the beginning of sampling process. The data were obtained through test then analyzed using $t$-test. The results showed that: 1) the cooperative learning with reciprocal teaching approach was effective for students' mathematical communication skills; 2) the cooperative learning with contextual teaching and learning approach was effective for students' mathematical communication skills; and 3) the cooperative learning with reciprocal teaching approach was more effective for students' mathematical communication skills than the cooperative learning with contextual teaching and learning approach. Thus, the result of this research was expected that the teachers do innovative teaching approach to enhance students' mathematics learning outcomes. Several of the teaching approaches that can be implemented are reciprocal teaching and contextual teaching and learning.

Keywords: Cooperative, Reciprocal Teaching, Contextual Teaching and Learning, Mathematical Communication

How to Cite: Gunur, B., Danus, Y. F., \& Jelatu, S. (2019). Model pembelajaran kooperatif dengan pendekatan reciprocal teaching dan contextual teaching and learning terhadap kemampuan komunikasi matematika siswa. MaPan: Jurnal Matematika dan Pembelajaran, 7(2), 229-248.

\section{PENDAHULUAN}

Tatematika merupakan salah satu mata pelajaran di sekolah yang memiliki peranan penting terhadap peningkatan kemampuan siswa dan merupakan suatu ilmu dasar yang mempunyai peranan 2012; Zaini \& Marsigit, 2014). Konsep dan prinsip matematika banyak digunakan dalam kehidupan sehari-hari, baik sebagai alat bantu dalam penerapan-penerapan bidang ilmu lain maupun dalam pengembangan matematika itu sendiri. Qohar \& Sumarmo (2013) menjelaskan bahwa matematika merupakan bahasa simbol yang harus dipelajari di setiap jenjang pendidikan. Pentingnya matematika diajarkan di setiap jenjang pendidikan dikarenakan matematika menjadi dasar bagi perkembangan ilmu yang lain.

Kemampuan komunikasi matematika merupakan salah satu kemampuan yang harus dimiliki oleh siswa. Kemampuan komunikasi matematika adalah kemampuan siswa untuk menyampaikan sesuatu yang diketahui melalui dialog atau hubungan timbal balik di dalam lingkungan kelas, pesan yang disampaikan berisi materi matematika, seperti konsep, formula, atau strategi pemecahan masalah (Rahmi, Nadia, Hasibah, \& 
Hidayat, 2017). Permendiknas no. 22 tahun 2006 tentang standar isi, menyatakan bahwa salah satu tujuan pembelajaran matematika yaitu agar peserta didik memiliki kemampuan mengomunikasikan gagasan dengan simbol, tabel, diagram, atau media lain untuk memperjelas keadaan atau masalah matematika (Depdiknas, 2006). Kemampuan komunikasi matematika sangat dibutuhkan siswa dalam pembelajaran matematika mengingat ilmu matematika memuat banyak simbol, tabel, dan diagram.

Komunikasi matematis merupakan suatu cara yang dilakukan siswa agar mampu berpikir dan bernalar tentang matematika yang merupakan sarana pokok dalam mengekspresikan hasil pemikiran siswa baik secara lisan maupun tertulis (NCTM, 2000). Kemampuan komunikasi matematika merupakan dasar dalam bermatematika agar siswa dapat mengekspresikan ide-ide matematika, seperti simbol, notasi, diagram baik secara lisan maupun tertulis yang membantu siswa lebih mudah memahami masalah dalam matematika (Surya, Syahpurta, \& Juniati, 2018). Melalui komunikasi, terdapat proses penyampaian ide atau gagasan secara lisan ataupun tulisan sehingga menciptakan pemahaman (Asnawati, 2017).

Kenyataan di lapangan menunjukkan bahwa sebagian besar siswa memiliki kemampuan komunikasi matematika yang rendah. Hal ini diketahui dari hasil tes yang diberikan kepada siswa berupa soal uraian yang berjumlah dua nomor yang memuat indikator komunikasi matematika. Berdasarkan hasil tes yang diberikan dari 27 orang siswa 11,1\% yang menjawab benar untuk soal nomor satu, 55,5\% menjawab soal nomor satu dan penyelesaiannya kurang tepat, dan 33,3\% siswa tidak menjawab dan hanya menuliskan kembali soal. Dengan demikian, dapat disimpulkan bahwa kemampuan komunikasi matematika siswa masih tergolong rendah.

Proses pembelajaran di kelas lebih cenderung menggunakan pembelajaran langsung atau pembelajaran yang berpusat pada guru (teacher centered). Pembelajaran langsung selalu didominasi oleh guru sehingga guru menjadi pemeran utama dalam pembelajaran. Pembelajaran langsung tidak memberi ruang kepada siswa untuk mengomunikasikan ide yang dimilikinya sehingga siswa menjadi pasif dalam pembelajaran. Idealnya, proses pembelajaran matematika melibatkan guru dan siswa sehingga guru tidak sepenuhnya mendominasi pembelajaran. Siswa perlu diberi kesempatan untuk berpikir aktif, kreatif, dan inovatif sehingga siswa dapat belajar mengomunikasikan pengetahuan yang dimilikinya selama proses pembelajaran. 
Menanggapi permasalahan tersebut, peneliti menawarkan dua model pembelajaran yang mendorong siswa agar dapat berpikir aktif, kreatif, dan inovatif sehingga dapat mengembangkan kemampuan komunikasi matematikanya. Model pembelajaran pertama adalah model pembelajaran kooperatif dengan pendekatan reciprocal teaching dan model pembelajaran kedua yaitu model pembelajaran kooperatif dengan pendekatan Contextual Teaching and Learning (CTL).

Model pembelajaran kooperatif merupakan kegiatan pembelajaran berkelompok yang membagi siswa dalam kelompok-kelompok kecil agar siswa bekerja sama saling membantu menyelesaikan permasalahan atau tugas yang sama sehingga dapat menciptakan interaksi antar peserta didik, sehingga peserta didik diharapkan dapat menguasai materi pelajaran dengan mudah karena memahami penjelasan dari temannya yang memiliki taraf pengetahuan dan pemikiran lebih sejalan dan sepadan (Agustyaningrum \& Widjajanti, 2013; Fahrullisa, Putra, \& Supriadi, 2018; Hutagalung, 2017; Purwaningsih, Sugiharto, \& Utami, 2013). Dengan demikian, siswa saling berbagi pengetahuan, pengalaman, tugas, dan tanggung jawab. Siswa juga belajar untuk saling menghargai kekurangan satu sama lain.

Reciprocal teaching merupakan pendekatan pembelajaran terbalik berdasarkan pada pemodelan dan praktek terbimbing yang menekankan pada pemahaman dalam membaca agar siswa diajarkan empat strategi pemahaman pengaturan diri spesifik, yaitu summarizing (merangkum), questioning (membuat pertanyaan), clarifying (klarifikasi) dan predicting (prediksi) (Ketong, Burhanuddin, \& Asri, 2018; Palincsar \& Brown, 2007; Yunita, Santosa, \& Ariyanto, 2011). Reciprocal teaching merupakan pendekatan pembelajaran yang memiliki manfaat agar tujuan pembelajaran tercapai melalui kegiatan belajar mandiri dan siswa mampu menjelaskan temuannya pada pihak lain (Sukardi, Susilo, \& Zubaidah, 2015; Yunita, Santosa, \& Ariyanto, 2011). Dengan demikian, model pembelajaran kooperatif dengan pendekatan reciprocal teaching merupakan model pembelajaran berkelompok sehingga siswa mengkonstruksi konsep dan menyelesaikan berbagai masalah dengan menerapkan strategi-strategi reciprocal.

Model pembelajaran kedua yaitu model pembelajaran kooperatif dengan pendekatan CTL. Pendekatan CTL merupakan pendekatan pembelajaran yang sesuai dengan kinerja otak, menekankan pada pembelajaran bermakna dan memungkinkan siswa dapat menggali, mengaitkan, dan mendiskusikan materi akademik dengan jalan 
menghubungkan mata pelajaran akademik dengan konteks kehidupan seharihari, baik konteks kehidupan pribadi, sosial, dan budaya (Harahap, 2015; Rofik, 2015; Surdin, 2018). Pembelajaran CTL menekankan pada keaktifan siswa dalam bekerja dan mengalami sampai proses penyelidikan yang dilakukan siswa serta membuat siswa lebih mandiri dan belajar menjadi lebih bermakna (Selvianiresa \& Prabawanto, 2017). Model pembelajaran kooperatif dengan pendekatan CTL perlu diterapkan dalam proses pembelajaran, sehingga siswa dapat bekerjasama dalam kelompok dan melaksanakan pembelajaran yang aktif dengan membangun pengetahuannya sendiri dan menghubungkannya dengan konteks dunia nyata. Dengan demikian, model pembelajaran kooperatif dengan pendekatan CTL merupakan model pembelajaran berkelompok yang membuat siswa dapat mengkonstruksi pengetahuan dengan jalan mengaitkan antara materi akademik yang dipelajari dengan situasi dunia nyata. Hasil penelitian yang dilakukan Ratnasari \& Saefudin (2018) menyimpulkan bahwa pendekatan CTL lebih efektif dibandingkan pembelajaran langsung ditinjau dari kemampuan komunikasi matematika siswa.

\section{METODE PENELITIAN}

Pretest-posttest only control group design merupakan desain yang digunakan dalam penelitian ini. Populasinya adalah seluruh siswa kelas $X$ SMK Santo Aloisius Ruteng yang tersebar dalam 5 kelas. Dalam penelitian ini, dipilih dua kelas secara acak, yang terlebih dahulu diuji kesetaraannya dengan menggunakan anava satu jalur. Dikatakan setara apabila $F_{\text {hitung }}<\mathrm{F}_{\text {tabel }}$, kemudian kelas-kelas yang setara dapat dijadikan sebagai kelas penelitian.

Tabel 1. Ringkasan Anava Uji Kesetaraan Kelas

\begin{tabular}{cccccc}
\hline \multirow{2}{*}{ SV } & \multirow{2}{*}{ JK } & Db & MK & $\mathbf{F}_{\mathbf{h}}$ & $\mathbf{F}_{\mathbf{t}}$ \\
\cline { 5 - 7 } & & & & $\mathbf{5} \%$ \\
$\mathrm{~K}$ & 486,6689 & 4 & 162,223 & 1,906 & 2,4236 \\
$\mathrm{D}$ & 14367,55 & 174 & 143,6755 & & \\
$\mathrm{~T}$ & 14854,22 & 178 & & & \\
\hline
\end{tabular}

Berdasarkan data yang diperoleh pada tabel 1, diketahui bahwa ketiga kelas setara karena $F_{\text {hitung }}=1,906<F_{\text {tabel }}=2,4236$. Dari kelima kelas dipilih dua kelas secara acak yang akan dijadikan sebagai kelas eksperimen satu dan kelas eksperimen dua. Berdasarkan hasil acak kelas yang dilakukan peneliti, 
kelas X TKR A dengan jumlah siswa sebanyak 34 terpilih sebagai kelas eksperimen satu yang menerapkan model pembelajaran kooperatif dengan pendekatan reciprocal teaching dan kelas X TKR C dengan jumlah siswa 33 terpilih sebagai kelas eksperimen dua yang menerapkan model pembelajaran kooperatif dengan pendekatan CTL.

Data dikumpulkan dengan menggunakan teknik tes yaitu tes pretest dan posttest. Instrumen terdiri dari 5 butir soal uraian yang disusun berdasarkan indikator kemampuan komunikasi matematis yang terdiri dari kemampuan memberikan gagasan suatu ide matematika, menjelaskan ide dan relasi matematika dengan gambar, menggunakan notasi dan struktur matematik dalam menyajikan ide dengan pembuatan model, menyatakan gambar dengan model matematika, dan mengapresiasi nilai-nilai dari suatu notasi matematis. Sebelum diberikan tes kepada siswa, terlebih dahulu dilakukan uji validitas dan reliabilitas instrumen. Validitas instrumen diuji menggunakan rumus korelasi product moment. Instrumen dikatakan valid apabila $r_{\text {hitung }} \geq \mathrm{r}_{\text {tabel }}$ pada taraf signifikan 5\%. Ringkasan hasil uji validitas instrumen kemampuan komunikasi matematika siswa yang disajikan pada tabel berikut:

Tabel 2. Hasil Uji Validitas Instrumen

\begin{tabular}{cccc}
\hline No soal & $\mathbf{R}_{\text {hitung }}$ & $\mathbf{r}_{\text {tabel }}$ & Keterangan \\
\hline 1 & 0.681 & 0.404 & Valid \\
2 & 0.462 & 0.404 & Valid \\
3 & 0.664 & 0.404 & Valid \\
4 & 0.519 & 0.404 & Valid \\
5 & 0.807 & 0.404 & Valid \\
\hline
\end{tabular}

Reliabilitas instrumen diuji menggunakan rumus alpha. Hasil uji reliabilitas instrumen yaitu sebesar 0,62 dengan kategori tinggi. Pengujian hipotesis pertama dan kedua menggunakan rumus one sample t-test yang bertujuan untuk mengetahui keefektifan model pembelajaran kooperatif dengan pendekatan reciprocal teaching dan model pembelajaran kooperatif dengan pendekatan CTL terhadap kemampuan komunikasi matematika siswa. Untuk pengujian hipotesis ketiga menggunakan uji $\mathrm{t}$ yaitu untuk mengetahui apakah model pembelajaran kooperatif dengan pendekatan reciprocal teaching lebih efektif dibandingkan model pembelajaran kooperatif 
dengan pendekatan CTL terhadap kemampuan komunikasi matematika siswa.

\section{HASIL PENELITIAN DAN PEMBAHASAN}

Pada penelitian ini pembelajaran dilaksanakan selama empat kali pertemuan setelah diberikan pretest. Proses pembelajaran pada kelas eksperimen satu menggunakan model pembelajaran kooperatif dengan pendekatan reciprocal teaching sedangkan kelas eksperimen dua menggunakan model pembelajaran kooperatif dengan pendekatan CTL.

Data kemampuan komunikasi matematika siswa diperoleh sebelum diterapkannya model pembelajaran pretest (tes awal) dan setelah diberikan posttest (tes akhir) pada siswa kelas eksperimen satu dan kelas eksperimen dua. Data tersebut dianalisis sehingga diperoleh statistik deskriptif dan statistik inferensial dari kedua kelas tersebut.

Tabel 3. Deskripsi Data Pretest dan Posttest Kelas Eksperimen Satu dan Kelas Eksperimen Dua

\begin{tabular}{ccccc}
\hline \multirow{2}{*}{ Statistik } & \multicolumn{2}{c}{ Kelas Eksperimen Satu } & \multicolumn{2}{c}{ Kelas Eksperimen Dua } \\
\cline { 2 - 5 } & Pretest & Posttest & Pretest & Posttest \\
\hline Rata-rata & 42,1 & 75,9 & 43,3 & 70,12 \\
Variansi & 154,3 & 41,1 & 258,7 & 55,5 \\
Standar Deviasi & 12,4 & 6,4 & 16,1 & 7,4 \\
Modus & 33,3 & 77,8 & 30,6 & 66,7 \\
Median & 36,1 & 76,4 & 33,3 & 69,4 \\
Data Maksimun & 66,7 & 88,9 & 69,4 & 83,3 \\
Data Minimum & 27.8 & 61,1 & 30,6 & 55,6 \\
Range & 38,9 & 27,8 & 38,8 & 27,7 \\
\hline
\end{tabular}

Pada tabel 3, terlihat bahwa data pretest siswa pada kelas eksperimen satu yang akan mengikuti model pembelajaran kooperatif dengan pendekatan reciprocal teaching sedikit lebih rendah dibandingkan dengan kelas eksperimen dua yang menggunakan model pembelajaran kooperatif dengan pendekatan CTL. Hal tersebut ditunjukan dengan nilai rata-rata siswa pada kelas eksperimen satu yang lebih rendah dibandingkan dengan nilai rata-rata siswa pada kelas eksperimen dua.

Data frekuensi nilai pretest kelas eksperimen satu dan kelas eksperimen dua dapat dilihat pada diagram berikut ini. 


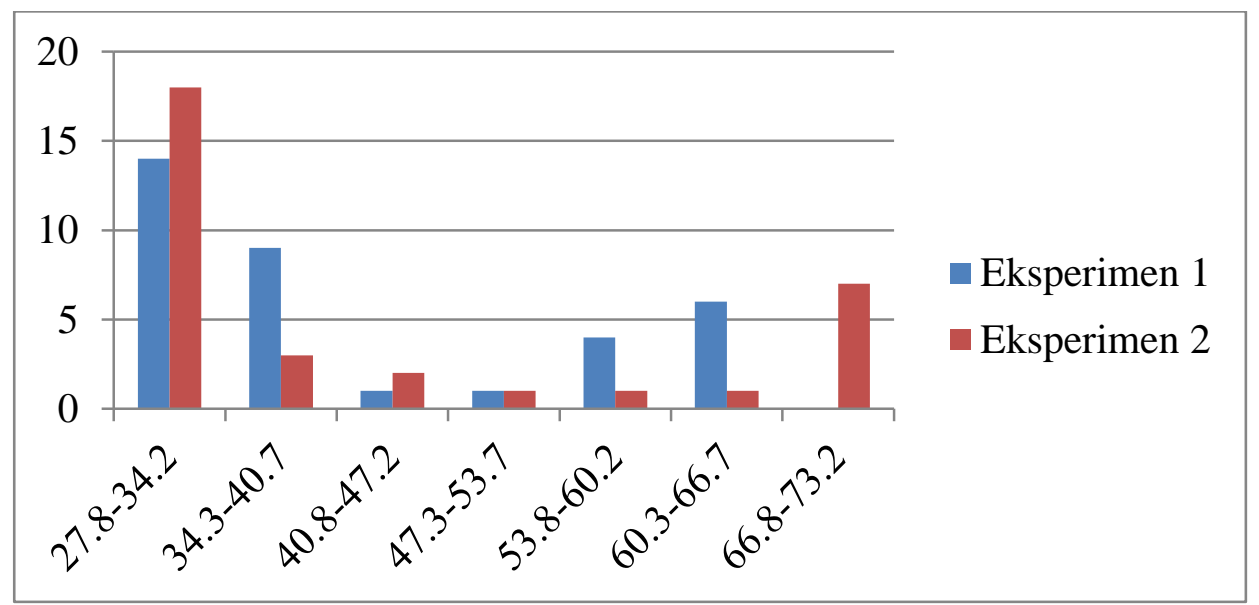

Gambar 1. Diagram Batang Pretest Kelas Eksperimen Satu dan Kelas Eksperimen Dua

Untuk data posttest kemampuan komunikasi matematis siswa pada kelas eksperimen satu yang akan mengikuti model pembelajaran kooperatif dengan pendekatan reciprocal teaching jauh lebih baik dibandingkan dengan kelas eksperimen dua yang menggunakan model pembelajaran kooperatif dengan pendekatan CTL. Hal tersebut ditunjukan dengan nilai rata-rata siswa pada kelas eksperimen satu mengalami peningkatan yang cukup tinggi dibandingkan dengan nilai rata-rata siswa pada kelas eksperimen dua.

Data frekuensi nilai posttest kelas eksperimen satu dan kelas eksperimen dua dapat dilihat pada diagram berikut ini:

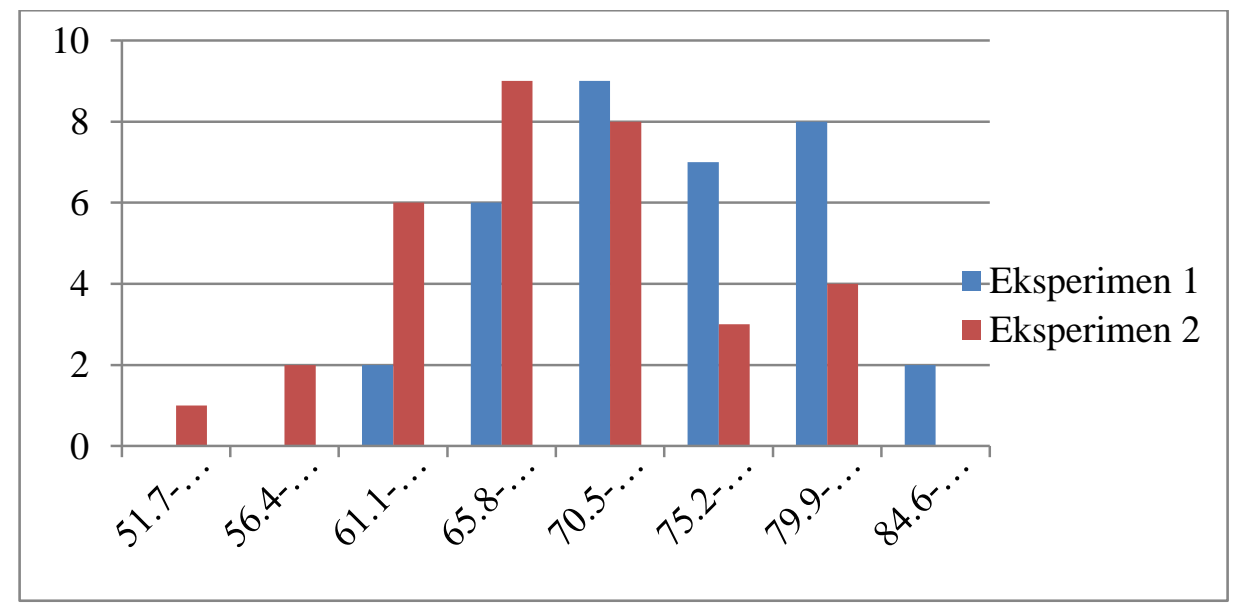

Gambar 2. Diagram Batang Posttest Kelas Eksperimen Satu dan Kelas Eksperimen Dua 
Berdasarkan data tersebut, nilai rata-rata posttest kelas eksperimen satu lebih tinggi daripada nilai rata-rata pada kelas eksperimen dua dengan selisih 5,8. Dengan demikian, nilai rata-rata posttest kemampuan komunikasi matematika siswa yang menerapkan pembelajaran kooperatif dengan pendekatan reciprocal teaching lebih tinggi dibandingkan dengan yang menerapkan model pembelajaran kooperatif dengan pendekatan CTL. Selain itu, deskripsi data tiap variabel diklasifikasi dalam lima kategori. Pengklasifikasian menggunakan mean ideal $\left(\mathrm{M}_{\mathrm{i}}\right)$ dan standar deviasi ideal $\left(\mathrm{SD}_{\mathrm{i}}\right)$. Kecenderungan klasifikasi data pretest dan data posttest pada kelas eksperimen satu dengan jumlah siswa serta persentase. Berikut penilaian acuan patokan disajikan dalam tabel.

Tabel 4. Sebaran Siswa pada Kelima Tingkat Kemampuan Komunikasi Matematis Skor Pretest Kelas Eksperimen Satu

\begin{tabular}{cccc}
\hline Interval Nilai & Kriteria & Jumlah Siswa & Persentase \\
\hline $\mathbf{X} \geq \mathbf{3 2}$ & Sangat Tinggi & 0 & - \\
$\mathbf{3 2}>X \geq \mathbf{2 3}$ & Tinggi & 0 & - \\
$\mathbf{2 3}>X \geq \mathbf{1 4}$ & Cukup Tinggi & 14 & $29,4, \%$ \\
$\mathbf{1 4}>\mathbf{X} \geq \mathbf{5}$ & Kurang Tinggi & 20 & $70,6 \%$ \\
$\mathbf{X}<\mathbf{5}$ & Sangat Kurang & 0 & - \\
\hline
\end{tabular}

Berdasarkan tabel 4, dapat disimpulkan bahwa interval nilai pretest kemampuan komunikasi matematika siswa pada kelas eksperimen satu berada pada kategori kurang tinggi dan cukup tinggi dengan persentase $70,6 \%$ siswa berada pada kategori kurang tinggi, dan 29,4\% siswa berada kategori cukup tinggi.

Tabel 5. Sebaran Siswa pada Kelima Tingkat Kemampuan Komunikasi Matematis Skor Posttest Kelas Eksperimen Satu

\begin{tabular}{cccc}
\hline Interval Nilai & Kriteria & Jumlah Siswa & Persentase \\
\hline $\mathbf{X} \geq \mathbf{3 2}$ & Sangat Tinggi & 0 & - \\
$\mathbf{3 2}>\mathbf{X} \geq \mathbf{2 3}$ & Tinggi & 33 & $97,1 \%$ \\
$\mathbf{2 3}>X \geq \mathbf{1 4}$ & Cukup Tinggi & 1 & $2,9 \%$ \\
$\mathbf{1 4}>\mathbf{X} \geq \mathbf{5}$ & Kurang Tinggi & 0 & - \\
$\mathbf{X}<\mathbf{5}$ & Sangat Kurang & 0 & - \\
\hline
\end{tabular}


Berdasarkan tabel 5, disimpulkan bahwa interval nilai posttest kemampuan komunikasi matematis siswa kelas eksperimen satu berada pada kategori cukup tinggi dan tinggi dengan persentase 2,9\% berada kategori cukup tinggi, 97,1\% berada kategori tinggi.

Tabel 6. Sebaran Siswa pada Kelima Tingkat Kemampuan Komunikasi Matematis Skor Pretest Kelas Eksperimen Dua

\begin{tabular}{cccc}
\hline Interval Nilai & Kriteria & $\begin{array}{c}\text { Jumlah } \\
\text { Siswa }\end{array}$ & Persentase \\
\hline $\mathbf{X} \geq \mathbf{3 2}$ & Sangat Tinggi & 0 & - \\
$\mathbf{3 2}>\mathbf{X} \geq \mathbf{2 3}$ & Tinggi & 0 & - \\
$\mathbf{2 3}>\mathbf{X} \geq \mathbf{1 4}$ & Cukup Tinggi & 12 & $36,4 \%$ \\
$\mathbf{1 4}>\mathbf{X} \geq \mathbf{5}$ & Kurang Tinggi & 21 & $63,6 \%$ \\
$\mathbf{X}<\mathbf{5}$ & Sangat Kurang & 0 & - \\
\hline
\end{tabular}

Berdasarkan tabel 6, disimpulkan bahwa interval nilai pretest kemampuan komunikasi matematis siswa kelas eksperimen dua berada pada kategori kurang tinggi dan cukup tinggi dengan persentase untuk kategori cukup kurang tinggi 63,6\% dan kategori cukup tinggi 36

Tabel 7. Sebaran Siswa pada Kelima Tingkat Kemampuan Komunikasi Matematis Skor Postest Kelas Eksperimen Dua

\begin{tabular}{cccc}
\hline Interval Nilai & Kriteria & $\begin{array}{c}\text { Jumlah } \\
\text { Siswa }\end{array}$ & Persentase \\
\hline $\mathbf{X} \geq \mathbf{3 2}$ & Sangat Tinggi & 0 & - \\
$\mathbf{3 2}>\mathbf{X} \geq \mathbf{2 3}$ & Tinggi & 29 & $87,9 \%$ \\
$\mathbf{2 3}>\mathbf{X} \geq \mathbf{1 4}$ & Cukup Tinggi & 4 & $12,1 \%$ \\
$\mathbf{1 4}>\mathbf{X} \geq \mathbf{5}$ & Kurang Tinggi & 0 & - \\
$\mathbf{X}<\mathbf{5}$ & Sangat Kurang & 0 & - \\
\hline
\end{tabular}

Berdasarkan tabel 7, disimpulkan bahwa interval nilai posttest kemampuan komunikasi matematis siswa kelas eksperimen dua berada pada kategori cukup tinggi dan tinggi dengan persentase $12,1 \%$ berada kategori cukup tinggi, 87,9\% berada kategori tinggi. Selanjutnya dilakukan pengujian hipotesis, yang didahului dengan melakukan uji prasyarat yaitu uji normalitas dan homogenitas. Hasil selengkapnya perhitungan uji normalitas dan homogenitas dapat dilihat pada tabel 8 . 
Tabel 8. Hasil Uji Normalitas Data

\begin{tabular}{lcccccc}
\hline & \multicolumn{3}{c}{ Kolmogorov-Smirnov $^{a}$} & \multicolumn{3}{c}{ Shapiro-Wilk } \\
\hline & Statistic & Df & Sig. & Statistic & Df & Sig. \\
Eksperimen 1 & .112 & 34 & $.200^{*}$ & .967 & 34 & .375 \\
Eksperimen 2 & .138 & 33 & .115 & .966 & 33 & .386 \\
\hline
\end{tabular}

Hasil perhitungan SPSS nilai signifikan pada kelas eksperimen satu 0,200 dan pada kelas eksperimen dua 0,115, keduanya >0,05 maka dapat disimpulkan kedua kelas tersebut berasal dari populasi yang berdistribusi normal.

Uji homogenitas dilakukan untuk mengetahui apakah sampel yang diteliti berasal dari populasi yang homogen atau tidak. Pengujian dilakukan menggunakan bantuan aplikasi SPSS 21, dengan ketentuan apabila nilai sig. levene's test of equality of error variances lebih besar dari nilai sig yang ditetapkan $(>0,05)$, maka semua kelompok data sampel memiliki variansi yang sama atau homogen.

Jika nilai sig tabel levene's test of equality of error variances kurang dari nilai sig yang ditetapkan $(<0,05)$, maka semua kelompok data sampel memiliki variansi yang tidak sama atau tidak homogen. Hasil uji homogenitas data dapat dilihat pada tabel 9.

Tabel 9. Uji Homogenitas Data

\begin{tabular}{cccc}
\hline Levene Statistic & $d f 1$ & $d f 2$ & Sig. \\
\hline 1.338 & 1 & 65 & .252 \\
\hline
\end{tabular}

Tabel 9 menunjukkan bahwa nilai siginifikansi $0,252 \geq 0,05$, maka $\mathrm{H}_{0}$ diterima dan $\mathrm{H}_{1}$ ditolak yang artinya bahwa data posttest kelas eksperimen satu dan kelas eksperimen dua berasal dari populasi yang homogen. Hasil perhitungan uji normalitas dan uji homogenitas data kemampuan komunikasi matematika siswa sebagai uji prasyarat untuk melakukan uji hipotesis terpenuhi, maka selanjutnya dilakukan uji hipotesis.

Uji hipotesis pertama dalam penelitian ini digunakan untuk mengetahui keefektifan model pembelajaran kooperatif dengan pendekatan reciprocal teaching. Hasil perhitungan uji one sample t-test untuk tes kemampuan komunikasi matematika siswa dapat dilihat pada tabel 10. 
Tabel 10 Hasil Uji Hipotesis 1

\begin{tabular}{|c|c|c|c|c|c|c|}
\hline & \multicolumn{6}{|c|}{ Test Value $=65$} \\
\hline & \multirow[t]{2}{*}{$T$} & \multirow[t]{2}{*}{$D f$} & \multirow{2}{*}{$\begin{array}{l}\text { Sig. (2- } \\
\text { tailed) }\end{array}$} & \multirow{2}{*}{$\begin{array}{c}\text { Mean } \\
\text { Difference }\end{array}$} & \multicolumn{2}{|c|}{$\begin{array}{c}95 \% \text { Confidence Interval of } \\
\text { the Difference }\end{array}$} \\
\hline & & & & & Lower & Upper \\
\hline VAR00001 & 9.968 & 33 & .000 & 10.9706 & 8.731 & 13.210 \\
\hline
\end{tabular}

Tabel 10 memperlihatkan bahwa nilai signifikan $\mathrm{t}$ hitung adalah $0,000 \leq 0,05$ maka $\mathrm{H}_{0}$ ditolak dan $\mathrm{H}_{1}$ diterima maka dapat disimpulkan bahwa model pembelajaran kooperatif dengan pendekatan reciprocal teaching efektif terhadap kemampuan komunikasi matematika siswa kelas X SMK Santo Aloisius Ruteng.

Model pembelajaran kooperatif dengan pendekatan reciprocal teaching efektif terhadap kemampuan komunikasi matematika siswa. Hal ini disebabkan karena model pembelajaran kooperatif dengan pendekatan reciprocal teaching merupakan pendekatan yang mengajarkan kepada siswa tentang empat strategi yang dilakukan siswa secara berkelompok yaitu summarizing, questioning, clarifying, dan predicting.

Pada model pembelajaran kooperatif dengan pendekatan reciprocal teaching, tahap pertama diawali dengan menyampaikan tujuan, menjelaskan alur pembelajaran, dan mengelompokkan siswa ke dalam kelompok secara heterogen yang terdiri dari 4 orang. Pada tahap kedua, guru membagikan kartu reciprocal. Setiap siswa mendapatkan satu kartu reciprocal yang akan menjadi pedoman saat diskusi berlangsung. Setelah setiap kelompok mendapatkan kartu diskusi, siswa memulai kegiatan diskusi dengan melakukan strategi pertama yaitu summarizing. Pada kegiatan summarizing ini, siswa yang telah mendapatkan summarizer's card bertugas membuat rangkuman untuk mengidentifikasi informasi penting dalam lembar soal dan menyajikannya dalam pernyataan yang jelas secara ringkas yang mengkomunikasikan makna penting dari permasalahan dalam lembar soal dengan bahasa mereka sendiri. Hal ini bertujuan agar siswa dapat membedakan hal-hal penting yang akan diselesaikan berkaitan dengan permasalahan yang diberikan. Strategi ini membantu siswa merangkum halhal penting yang disajikan dalam lembar soal, dengan demikian setiap anggota kelompok akan mendapatkan informasi dari teman kelompok yang bertugas merangkum terkait hal-hal penting yang diketahui dari masalah yang disajikan. Setelah membuat rangkuman, siswa yang bertugas kemudian 
membacakan hasil rangkumannya dan meminta teman kelompok untuk memperhatikan dan memberi masukkan apabila masih ada yang kurang dan terdapat kekeliruan. Dengan demikian, hal ini membantu siswa untuk mengungkapkan informasi dari masalah yang disajikan dalam bentuk tulisan, kemudian mengungkapkan secara lisan. Hal ini dapat melatih siswa untuk mengkomunikasikan ide atau pendapat dari masalah yang disajikan, sehingga dapat membantu siswa mengembangkan kemampuan komunikasinya. Hal ini sejalan dengan pernyataan Doolittle, Hicks, Triplett, Nichols, \& Young (2006) yang mengatakan bahwa merangkum memberikan dorongan untuk menciptakan konteks untuk memahami spesifikasi suatu teks. Dengan demikian, siswa dilatih untuk berpikir dan menuliskan informasi yang diperoleh dari masalah yang disajikan serta mengkomunikasikannya.

Strategi kedua yang diterapkan yaitu questioning (membuat pertanyaan). Pada tahapan ini siswa yang mendapatkan quistioner's card bertugas membuat pertanyaan dari masalah yang ada kemudian membacakan pertanyaan yang telah dibuatnya, kemudian menanyakan pendapat dari teman kelompok dan meminta teman kelompok menanggapi. Dengan demikian, siswa mendapatkan kesempatan untuk mengkomunikasikan ide yang dimilikinya dan memberikan kesempatan teman kelompok untuk memberikan seluruh jenis pertanyaan. Tahapan ini digunakan untuk memonitor dan mengevaluasi sejauh mana pemahaman siswa terhadap materi yang telah dibacakan. Dalam hal ini pembaca adalah siswa dalam kelompok tersebut, siswa mengajukan pertanyaan-pertanyaan kepada diri sendiri yang kemudian akan disampaikan kepada teman-teman sekelompok. Hal ini sejalan dengan pernyataan Palincsar \& Brown (2007) yang mengatakan bahwa membuat pertanyaan melibatkan identifikasi informasi, tema, dan ide-ide yang penting untuk menjamin pertimbangan lebih lanjut. Informasi, tema, atau ide sentral atau penting digunakan untuk menghasilkan pertanyaan yang kemudian digunakan sebagai tes mandiri untuk pembaca.

Strategi ketiga yang diterapkan dalam diskusi yaitu clarifying (klarifikasi). Pada tahapan ini, guru menugaskan siswa yang mendapatkan clarifier's untuk menjelaskan (clarif ying) kepada teman satu kelompoknya tentang materi yang telah didiskusikan. Hal ini bertujuan agar siswa dapat mencerna makna dari kata atau kalimat yang tidak familiar dari permasalahan yang disajikan. Dengan demikian, siswa yang bertugas mendapatkan kesempatan mengkomunikasikan ide yang dimilikinya. Teman kelompok bertugas untuk menanggapi dan kemudian bersama-sama mencari tahu 
makna dari kata yang tidak familiar tersebut apabila masih kurang jelas. Hal ini membantu siswa untuk bekerja sama dan mendorong siswa aktif berdiskusi sehingga secara perlahan dapat membantu mengembangkan kemampuan komunikasi yang dimiliki. Pada tahapan ini, siswa belajar berdasarkan paham konstruktivis dengan jalan menemukan dan membangun sendiri konsep dari materi yang dipelajari. Hal ini sejalan dengan teori konstruktivis sosial Vygotsky yang mengatakan bahwa reciprocal teaching didasarkan pada sosialisasi antara guru dan siswa atau antara siswa dan siswa. Dalam hal ini konstruk pengetahuan melalui dialog bukan melalui transfer pengetahuan dari guru ke siswa.

Strategi terakhir yaitu predicting (membuat prediksi), siswa yang mendapatkan predictor's card memprediksi soal yang lebih sulit dari soal yang diberikan dan memprediksi pertanyaan apa yang akan muncul dari penjelasan kelompoknya saat hasil diskusi dipresentasikan. Siswa diarahkan untuk melakukan apersepsi untuk mengingatkan kembali materi yang telah dipelajari atau diperoleh sebelumnya, kemudian dikaitkan dengan informasi yang diperoleh dari konsep yang dibaca. Setelah memprediksi, siswa yang bertugas mengkomunikasikan hasil prediksi kepada teman kelompok dan meminta teman kelompok untuk menanggapi hasil prediksi. Hal ini membantu siswa untuk mengkomunikasikan ide dalam bentuk tulisan terkait pertanyaan yang akan muncul saat presentasi kelompok di depan kelas, sehingga anggota kelompok telah mempersiapkan hal apa saja yang akan dikomunikasikan apabila terdapat pertanyaan-pertanyaan dari kelompok lain. Proses seperti ini dapat mengembangkan kemampuan komunikasi yang dimiliki secara perlahan. Hasil dan temuan dalam penelitian ini sejalan dengan penelitian yang dilakukan oleh Ketong, Burhanuddin, \& Asri (2018) dan Yunita, Santosa, \& Ariyanto (2011) yang menyimpulkan bahwa model pembelajaran kooperatif dengan pendekatan reciprocal teaching efektif daripada model pembelajaran langsung. Sedangkan penelitian Syidhi \& Listyani (2017) menyimpulkan bahwa model pembelajaran reciprocal teaching lebih efektif dibandingkan dengan model pembelajaran saintifik ditinjau dari kemampuan pemecahan masalah matematis. Uji hipotesis kedua dalam penelitian ini digunakan untuk mengetahui keefektifan model pembelajaran kooperatif dengan pendekatan CTL. Hasil perhitungan tes kemampuan komunikasi matematika siswa dapat dilihat pada tabel 11. 
Tabel 11. Hasil Uji Hipotesis 2

\begin{tabular}{|c|c|c|c|c|c|c|}
\hline & \multicolumn{6}{|c|}{ Test Value $=65$} \\
\hline & \multirow[t]{2}{*}{$T$} & \multirow[t]{2}{*}{ df } & \multirow{2}{*}{$\begin{array}{l}\text { Sig. (2- } \\
\text { tailed) }\end{array}$} & \multirow{2}{*}{$\begin{array}{c}\text { Mean } \\
\text { Difference }\end{array}$} & \multicolumn{2}{|c|}{$\begin{array}{l}\text { 95\% Confidence Interval } \\
\text { of the Difference }\end{array}$} \\
\hline & & & & & Lower & Upper \\
\hline VAR00002 & 3.950 & 32 & .000 & 5.1212 & 2.480 & 7.762 \\
\hline
\end{tabular}

Dari hasil analisis, diketahui bahwa nilai signifikan $0,000 \leq 0,05$ maka $\mathrm{H}_{0}$ ditolak dan $\mathrm{H}_{1}$ diterima, maka disimpulkan bahwa model pembelajaran kooperatif dengan pendekatan CTL efektif terhadap kemampuan komunikasi matematika siswa kelas X SMK Santo Aloisius Ruteng. Pembelajaran kooperatif dengan pendekatan CTL diawali dengan penyajian masalah kontekstual, yang bertujuan agar siswa dapat mengalami langsung situasi nyata yang sesuai dengan pengalaman mereka. Sanjaya (2008) mengatakan bahwa pembelajaran kontekstual menekankan proses keterlibatan siswa untuk menemukan materi, menghubungkan materi yang dipelajari dengan situasi dunia nyata. Tahap selanjutnya, siswa dibentuk dalam kelompok dan diarahkan untuk mengaitkan masalah dalam kehidupan sehari-hari siswa dengan masalah matematika yang disajikan. Proses diskusi dipimpin oleh pemimpin diskusi. Selama proses diskusi, pemimpin diskusi bertugas untuk memimpin jalannya diskusi. Setiap anggota kelompok bekerja sama untuk menyelesaikan masalah-masalah yang disajikan. Dengan demikian, siswa diberi kesempatan seluas-luasnya untuk mengkomunikasikan ide-ide matematika yang dimilikinya selama proses diskusi berlangsung.

Model pembelajaran kooperatif dengan pendekatan CTL dapat membantu siswa untuk mengembangkan kemampuan komunikasi matematikanya. Hal ini dikarenakan dalam pembelajaran siswa berperan aktif dalam diskusi kelompok sedangkan guru hanya sebagai fasilitator. Proses ini dapat membantu menciptakan pembelajaran menjadi efektif dengan cara mengaitkan materi pembelajaran dengan konteks kehidupan siswa, sehingga siswa menjadi lebih aktif dalam diskusi untuk mengkomunikasikan ide-ide matematika yang dimilikinya. Hasil dan temuan dalam penelitian ini, sejalan dengan hasil penelitian Ratnasari \& Saefudin (2018) yang menyimpulkan bahwa pendekatan CTL lebih efektif dibandingkan model pembelajaran langsung ditinjau dari kemampuan komunikasi matematika siswa. Hal ini disebabkan karena dalam proses pembelajarannya siswa berperan aktif menemukan konsep dari materi yang dipelajari yang kemudian membantu 
siswa menyelesaikan masalah matematika dengan jalan mengaitkannya dengan situasi dunia nyata. Uji hipotesis ketiga dalam penelitian ini digunakan untuk membandingkan keefektifan model pembelajaran kooperatif dengan pendekatan reciprocal teaching dan model pembelajaran kooperatif dengan pendekatan CTL terhadap kemampuan komunikasi matematika siswa.

Tabel 12. Hasil Uji Hipotesis 3

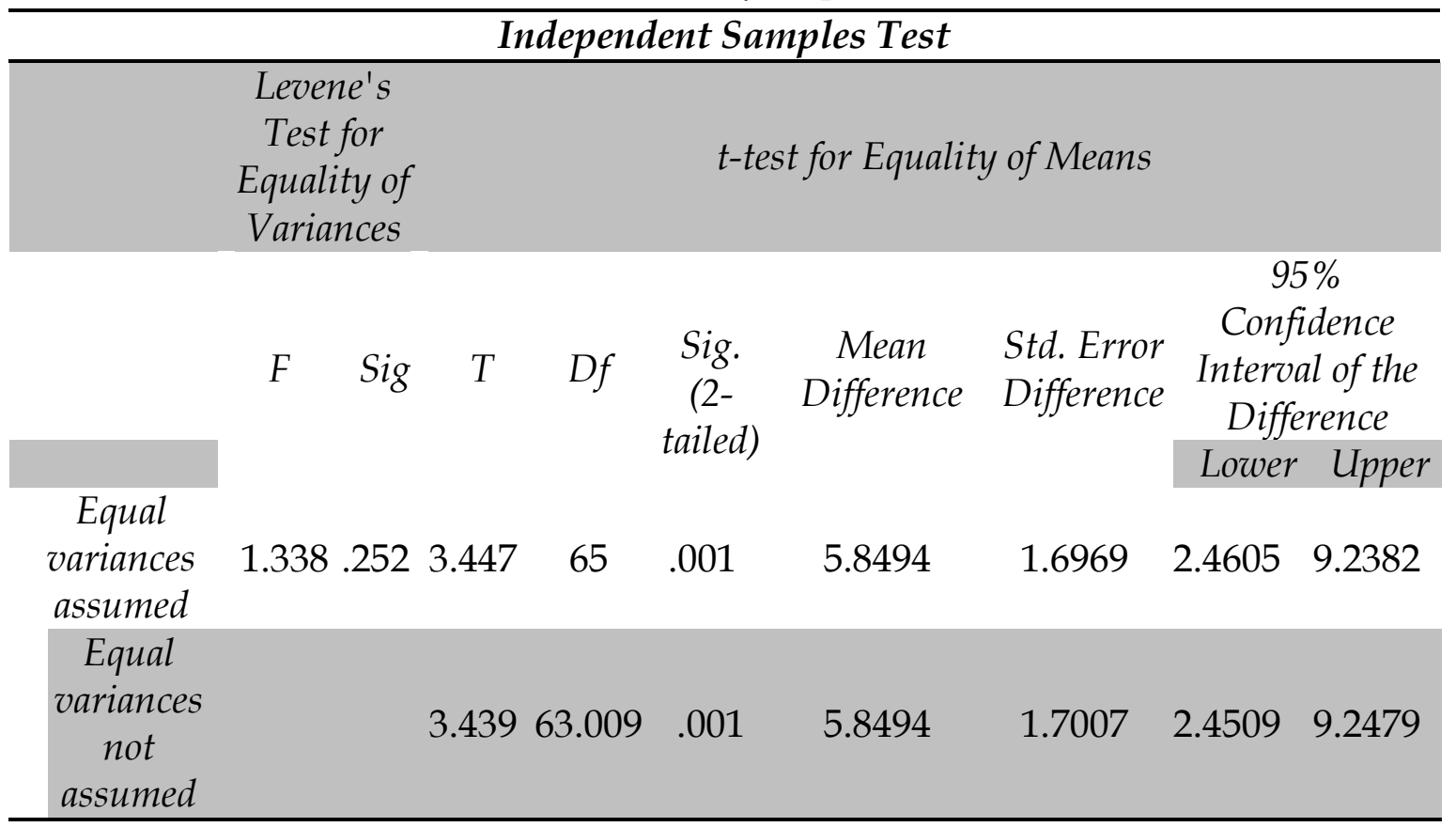

Tabel 12 menunjukkan nilai signifikan 0,001 $\leq$ 0,05, maka $\mathrm{H}_{0}$ ditolak dan $\mathrm{H}_{1}$ diterima. Artinya, model pembelajaran kooperatif dengan pendekatan reciprocal teaching lebih efektif dibandingkan model pembelajaran kooperatif dengan pendekatan CTL terhadap kemampuan komunikasi matematika siswa kelas X SMK Santo Aloisius Ruteng.

Berdasarkan penjelasan tersebut, baik model pembelajaran kooperatif dengan pendekatan reciprocal teaching dan model pembelajaran kooperatif dengan pendekatan CTL efektif terhadap kemampuan komunikasi matematika siswa. Kedua model pembelajaran ini memberikan kesempatan seluas-luasnya kepada siswa untuk mengemukakan pendapat atau ide-ide matematikanya ke dalam bahasa atau simbol-simbol matematika. Selain itu, kedua model pembelajaran ini merupakan pembelajaran berkelompok yang diawali dengan penyajian masalah-masalah kontekstual sehingga membantu siswa mengaitkan materi yang dipelajari dengan situasi dunia nyata siswa. 
Akan tetapi, dari kedua model pembelajaran tersebut, model pembelajaran kooperatif dengan pendekatan reciprocal teaching lebih efektif dibandingkan model pembelajaran kooperatif dengan pendekatan CTL.

Dikatakan demikian, pada model pembelajaran kooperatif dengan pendekatan reciprocal teaching siswa berdiskusi dengan menerapkan empat strategi yaitu summarizing, questioning, clarifying, dan predicting. Setiap siswa yang telah mendapatkan kartu reciprocal harus bertanggung jawab atas perannya. Dengan demikian, setiap siswa wajib mengemukakan ide atau pendapat selama proses diskusi. Hal ini dapat membantu terciptanya pembelajaran yang efektif sehingga membantu siswa mengembangkan kemampuan komunikasinya. Sedangkan pada model pembelajaran kooperatif dengan pendekatan CTL, siswa tidak mendapatkan kartu tahapan diskusi dan tidak melakukan tahapan seperti pada model pembelajaran kooperatif dengan pendekatan reciprocal teaching. Proses diskusi diarahkan oleh pemimpin diskusi. Akan tetapi, proses diskusi tidak memiliki tahapan yang jelas dan tidak semua siswa aktif berdiskusi sehingga tidak membantu mengembangkan kemampuan komunikasi matematikanya. Hal ini diketahui, ketika ditanyakan saat presentasi kelompok hanya beberapa siswa yang aktif menjawab, sedangkan siswa lain hanya diam. Ditemukan pula beberapa siswa terlihat kurang bersemangat saat berdiskusi dalam kelompok. Hal seperti inilah yang membuat siswa sulit untuk mengkomunikasikan ide matematikanya, sehingga kemampuan komunikasi matematikanya cukup rendah. Selain itu, diskusi hanya befokus pada penyelesaian masalah, sehingga tidak melatih kemampuan komunikasi matematika siswa.

Berdasarkan pembahasan di atas dapat disimpulkan bahwa penggunaan model pembelajaran kooperatif dengan pendekatan reciprocal teaching lebih efektif dibandingkan model pembelajaran kooperatif dengan pendekatan CTL terhadap kemampuan komunikasi matematika siswa. Hal ini berarti siswa yang mengikuti pembelajaran dengan model pembelajaran kooperatif dengan pendekatan reciprocal teaching di kelas memiliki kemampuan komunikasi matematika yang lebih baik dibandingkan siswa yang mengikuti model pembelajaran kooperatif dengan pendekatan CTL.

\section{SIMPULAN}

Berdasarkan hasil penelitian dan pembahasan dapat disimpulkan bahwa: (1) model pembelajaran kooperatif dengan pendekatan reciprocal teaching efektif terhadap kemampuan komunikasi matematika siswa kelas $\mathrm{X}$ 
SMK Santo Aloisius Ruteng; (2) model pembelajaran kooperatif dengan pendekatan CTL efektif terhadap kemampuan komunikasi matematika siswa kelas X SMK Santo Aloisius Ruteng; dan (3) model pembelajaran kooperatif dengan pendekatan reciprocal teaching lebih efektif dibandingkan model pembelajaran kooperatif dengan pendekatan CTL terhadap kemampuan komunikasi matematika siswa siswa kelas X SMK Santo Aloisius Ruteng.

\section{DAFTAR PUSTAKA}

Agustyaningrum, N., \& Widjajanti, D. B. (2013). Pengaruh pendekatan CTL dengan setting kooperatif tipe kancing gemerincing terhadap kemampuan komunikasi matematis, kepercayaan diri, dan prestasi belajar matematika siswa SMP. Phytagoras: Jurnal Pendidikan Matematika, 8(2), 171-180. Retrieved from https://journal.uny.ac.id/index.php/py thagoras/article/view/8946/pdf.

Asnawati, S. (2017). Peningkatan kemampuan komunikasi matematis siswa smp dengan pembelajaran kooperatif tipe teams-gamestournaments. Jurnal Euclid, 3(2), 561-567. https:/ / doi.org/doi.org/10.33603/e.v3i2. 332.

Depdiknas. (2006). Permendiknas no 22 tahun 2006 tentang standar isi. Jakarta: Departemen Pendidikan Nasonal RI.

Doolittle, P., Hicks, D., Triplett, C., Nichols, W., \& Young, C. (2006). Reciprocal teaching for reading comprehension in higher education: A strategy for fostering the deeper understanding of texts. International Journal of Teaching and Learning in Higher Education, 17(2), 106-118. Retrieved from https://pdfs.semanticscholar.org/1916/159cca2ce7e4f452c3ca081cbdc5 dbf22abd.pdf.

Duha, A. K., Yerizon, \& Suherman. (2012). Penerapan model think pair share terhadap pemahaman konsep. Jurnal Pendidikan Matematika, 1(1), 8-12. Retrieved from https://docplayer.info/61939966-Penerapan-modelthink-pair-share-terhadap-pemahaman-konsep.html.

Fahrullisa, R., Putra, F. G., \& Supriadi, N. (2018). Pengaruh model pembelajaran kooperatif Tipe Think Pair Share (TPS) berbantuan pendekatan investigasi terhadap kemampuan komunikasi matematis. NUMERICAL: Jurnal Matematika dan Pendidikan Matematika, 2(2), 145152. https:/ / doi.org/doi.org/10.25217/numerical.v2i2.213.

Harahap, T. H. (2015). Penerapan contextual teaching and learning untuk meningkatkan kemampuan koneksi dan representasi matematika siswa kelas VII-2 SMP Nurhasanah Medan tahun pelajaran 2012/2013. Jurnal EduTech, 1(1). Retrieved from https:/ / media.neliti.com/media/publica tions / 42693-ID-penerapan-contextual-teaching-and-learning-ctl-untukmeningkatkan-kemampuan-kone.pdf. 
Hutagalung, R. (2017). Peningkatan kemampuan pemahaman konsep matematis siswa melalui pembelajaran guided discovery berbasis budaya toba di SMP Negeri 1 Tukka. MES (Journal of Mathematics Education and Science), 2(2), 70-77. Retrieved from https://jurnal.uisu.ac.id/index.php/mesuisu/article/view/133/110.

Ketong, S., Burhanuddin, \& Asri, W. K. (2018). Keefektifan model pembelajaran reciprocal teaching dalam kemampuan membaca memahami siswa kelas XI IPA SMA Negeri 11 Makassar. Eralingua: Jurnal Pendidikan Bahasa Asing dan Sastra, 2(1), 45-54. Retrieved from https:/ / ojs.unm.ac.id/eralingua/article/viewFile/5629/3274

NCTM. (2000). Principles and standards for school mathematics. Reston, VA: NCTM.

Palincsar, A. S., \& Brown, A. L. (2007). Reciprocal teaching of comprehensionmonitoring activities. University of Illinois at Urbana-Champaign.

Purwaningsih, R., Sugiharto, \& Utami, B. (2013). Studi komparasi metode pembelajaran kooperatif tipe Numbered Heads Together (NHT) dan Think Pair Share (TPS) dengan media roda impian terhadap prestasi belajar siswa pada pokok bahasan sistem periodik unsur kelas $X$ Semester 1 SMAN I Purwantoro tahun pelajaran 2012/2013. JPK, Jurnal Pendidikan Kimia, 2(2), 66-74. Retrieved from https:/ / core.ac.uk/download/pdf/20332879.pdf.

Qohar, A., \& Sumarmo, U. (2013). Improving mathematical communication ability and self regulation learning of yunior high students by using reciprocal teaching. IndoMS. J. M. E, 4(1), 59-74. Retrieved from https:// ejournal.unsri.ac.id/index.php/jme/article/view/562/160.

Rahmi, S., Nadia, R., Hasibah, B., \& Hidayat, W. (2017). The relation between self-efficacy toward math with the math communication competence. Infinity Journal, 6(2), 177-182. https:/ / doi.org/10.22460/infinity.v6i2.p177-182.

Ratnasari, S. F., \& Saefudin, A. A. (2018). Efektivitas pendekatan Contextual Teaching and Learning (CTL) ditinjau dari kemampuan komunikasi matematika siswa. MaPan : Jurnal Matematika dan Pembelajaran, 6(1), 119127. https:/ / doi.org/10.24252/mapan.2018v6n1a11.

Rofik, A. (2015). Pembelajaran matematika model contextual teacing and learning dengan pendekatan problem posing berbantuan elearning materi dimensi tiga kelas $X$ untuk meningkatkan kemampuan pemecahan masalah. Jurnal Euclid, 2(2), 352-358. https:/ / doi.org/doi.org/10.33603/e.v2i2.369.

Sanjaya, W. (2008). Pembelajaran dalam implementasi kurikulum berbasis kompetensi. Jakarta: Kencana.

Selvianiresa, D., \& Prabawanto, S. (2017). Contextual teaching and learning approach of mathematics in primary schools. Journal of Physics: 
Conference Series, 895(1), 1-7. https://doi.org/10.1088/17426596/895/1/012171.

Sukardi, A. D., Susilo, H., \& Zubaidah, S. (2015). Pengaruh pembelajaran reciprocal teaching berbantuan peta pikiran (mind map) terhadap kemampuan metakognitif dan hasil belajar siswa SMA. JPS (Jurnal Pendidikan Sains), 3(2), 81-89. https:// doi.org/10.17977/jps.v3i2.7656.

Surdin. (2018). The effect of contextual teaching and learning (ctl) models on learning outcomes of social sciences of the material of forms the face of the earth on class VII of junior high school. International Journal of Education and Research, 6(3), 57-64. Retrieved from https://www.ijern.com/journal/2018/March-2018/08.pdf.

Surya, E., Syahpurta, E., \& Juniati, N. (2018). Effect of problem based learning toward mathematical communication ability and self-regulated learning. Journal of Education and Practice, 9(6), 14-23. Retrieved from https://pdfs.semanticscholar.org/0d28/da678a036373c69aa11846002f2 802a1a1cd.pdf.

Syidhi, S. M., \& Listyani, E. (2017). Effectiveness of reciprocal teaching model with concept mapping strategy in terms of mathematical problem solving skills of junior high school students. Jurnal Pendidikan Matematika dan Sains, 6(7), 35-45. Retrieved from http://journal.student.uny.ac.id/ojs/index.php/pmath/article/downl oad/7873/7499.

Yunita, Y. E., Santosa, S., \& Ariyanto, J. (2011). Penerapan pendekatan pengajaran terbalik (reciprocal teaching) untuk meningkatkan kemandirian belajar biologi siswa kelas VII-G SMP N 5 Karanganyar tahun pelajaran 2010/2011. Jurnal Pendidikan Biologi, 3(2), 43-54. Retrieved from https://media.neliti.com/media/publications/118837ID-penerapan-pendekatan-pengajaran-terbalik.pdf.

Zaini, A., \& Marsigit, M. (2014). Perbandingan keefektifan pembelajaran matematika dengan pendekatan matematika realistik dan konvensional ditinjau dari kemampuan penalaran dan komunikasi matematik siswa. Jurnal Riset Pendidikan Matematika, 1(2), 152-163. https:// doi.org/10.21831/jrpm.v1i2.2672. 